\title{
Assessing the recovery from prerenal and renal acute kidney injury after treatment with single herbal medicine via activity of the biomarkers HMGB1, NGAL and KIM-1 in kidney proximal tubular cells treated by cisplatin with different doses and exposure times
}

Sung-Man Oh, Gunhyuk Park, Seung Hoon Lee, Chang-Seob Seo, Hyeun-Kyoo Shin and Dal-Seok Oh ${ }^{*}$

\begin{abstract}
Background: Acute kidney injury (AKI) is an initial factor in many kidney disorders. Pre- and intra-renal AKI biomarkers have recently been reported. Recovery from AKI by herbal medicine has rarely been reported. Thus, this study aimed to investigate the dose- and time-dependent effects of herbal medicines to protect against AKI in cisplatin-induced human kidney 2 (HK-2) cells by assessing the activities of high-mobility group box protein 1 (HMGB1), neutrophil gelatinaseassociated lipocalin (NGAL) and kidney injury molecule-1 (KIM-1).

Methods: Proximal tubular HK-2 cell lines were treated with either $400 \mu \mathrm{M}$ of cisplatin for $6 \mathrm{~h}$ or $10 \mu \mathrm{M}$ of cisplatin for $24 \mathrm{~h}$ and then exposed to ten types of single herbal medicines, including Nelumbo nymphaea (NY) at a dose of $100 \mathrm{\mu g} / \mathrm{mL}$. The AKI biomarkers HMGB1, NGAL and KIM-1 were repeatedly measured by an ELISA assay at 2, 4, and $6 \mathrm{~h}$ in the group treated with $400 \mu \mathrm{M}$ of cisplatin to confirm necrotic cell death and at 6, 24, and $48 \mathrm{~h}$ in the group treated with $10 \mu \mathrm{M}$ of cisplatin to examine apoptotic cell death. Recovery confirm was conducted through in vivo study using ICR mice for 3 day NY or Paeonia suffruticosa intake.
\end{abstract}

Results: Cisplatin treatment at a concentration of $10 \mu \mathrm{M}$ decreased cell viability. Treatment with $400 \mu \mathrm{M}$ of cisplatin reduced HMBG1 activity and resulted in lactate dehydrogenase release. In longer exposure durations (up to $48 \mathrm{~h}$ ), NGAL and KIM-1 exhibited activity from $24 \mathrm{~h}$ onward. Additionally, NY treatment resulted in an approximately $50 \%$ change in all three biomarkers. The time-dependent profiles of HMGB1, NGAL and KIM-1 activities up to $48 \mathrm{~h}$ were notably different; HMGB1 exhibited a 7-fold change at 6 h, and NGAL and KIM-1 exhibited 1.7-fold changes at 24 h, respectively. Consistently, serum and urine NGAL and KIM-1 activities were all reduced in ICR mice.

Conclusions: Several single herbal medicines, including NY, have a potential as effectors of AKI due to their ability to inhibit the activation of HMGB1, NGAL and KIM-1 in an in vitro AKI-mimicked condition and simple in vivo confirm. Furthermore, an in vivo proof-of-concept study is needed.

Keywords: Acute kidney injury, Herbal medicine, High-mobility group box protein 1, Neutrophil gelatinase-associated lipocalin, Kidney injury molecule-1

\footnotetext{
* Correspondence: dalsoh@gmail.com; dsoh@kiom.re.kr

The K-herb Research Center, Korea Institute of Oriental Medicine, 1672

Yuseong-daero, Yuseong-gu, Daejeon 34054, Republic of Korea
} 


\section{Background}

Acute kidney injury (AKI, previously termed acute renal failure) refers to a clinical symptoms characterized by intrinsic renal malfunction [1]. AKI is defined to increase in serum creatinine within 2 to 7 days and the decreased kidney function [2]. Among the AKIs, prerenal and intrinsic AKI frequently coexist that urinary neutrophil gelatinase-associated lipocalin (NGAL), interleukin-18 (IL-18), and albumin show clinically significant elevated concentration in renal disease patients than non-AKI patients do [3]. One of the interesting properties in prerenal AKI is that it is recovered in a reversible manner. During that course, some natural anti-inflammatory or anti-oxidant agents have known to exert their functions to accelerate the recovery.

In the past, herbal medicine has not been studied regarding kidney injury due to the intoxicated episodes by several one. Chinese herbals caused the renal interstitial fibrosis as toxicant roles. i.e., Stephania tetrandra contains aristolochic acids, which functions were directly involved in tumorigenesis in rats [4]. Recent attention has been paid to herbal medicine for their potency of ameliorating kidney injuries. Several reports dealing with the benefits of herbals that they promote the main kidney functions of reabsorption, filtration and excretion of glomeruli. From the recent change of perspectives on herbals, we were interested in investigating herbal medicine's protective effects on acute kidney disorders including prerenal and renal AKIs.

Cisplatin was used to chemotherapeutic agents, derivative of platinum, to treat solid tumors. It was frequently limited by side effects such as ototoxicity, nephrotoxicity [5]. Cisplatin-induced AKI precedes proximal tubular dysfunction and impairment tubular reabsorption [6]. Cisplatin's higher concentration and shorter-time exposure has been introduced to be an AKI inducible factor [7]. The human kidney 2 (HK-2) cells were treated with higher concentrations of cisplatin versus the treatment with lower concentration presented different cell death either necrosis or apoptosis, respectively [8]. Recent studies have shown the apoptotic phenotypes induced by cisplatin in tubular cells, but those regarding necrosis has been lacking in tubular cells.

Prerenal and renal AKI biomarkers have been listed that neutrophil-gelatinase-associated lipocalin (NGAL), kidney injury molecule-1 (KIM-1) and highmobility group box protein-1 (HMGB1) have been studied to indicate kidney injury [9]. In the initiation of kidney injuries, each biomarker, HMGB1 and NGAL, KIM-1 have been reported different expressional timelines, different pre-treatment process, even revealed the different cell deaths; acute tubular necrosis or apoptosis $[10,11]$. That is why European Medicines Agency recommends them as experimental use as robust kidney injury biomarkers.

It was hypothesized that according to cisplatin concentration and expose timeline, firstly we can set the necrotic and apoptotic normal renal proximal tubular epithelial cell deaths and those setting could be regulated by food and non-food originated herbal medicines, thus, the purpose of the study was to investigate the effects of those herbal medicines on anti-AKI in cisplatin-induced HK-2 cells.

\section{Methods \\ Cell culture}

HK-2 human kidney proximal tubule epithelial cells were cultured in keratinocyte serum-free media supplemented with $50 \mathrm{ng} / \mathrm{ml}$ bovine pituitary extract and human recombinant epidermal growth factor at a concentration of $5 \mathrm{ng} / \mathrm{ml}$, according to the American Type Culture Collection (ATCC, URL www.atcc.org), in a humidified incubator at $37{ }^{\circ} \mathrm{C}$ in $5 \% \mathrm{CO}_{2}$. The cells were seeded in 96- and 6-well plates at densities of $1 \times 10^{4}$ and $2 \times 10^{5}$ cells/well, respectively.

\section{Chemicals and reagents}

Phosphate buffered saline, penicillin-streptomycin and fetal bovine serum were purchased from Gibco (MD, USA). N-acetylcysteine (NAC) and dimethylsulfoxide were purchased from Sigma-Aldrich (St. Louis, USA). All other reagents used were of guaranteed or analytical grade.

\section{Herbal raw material acquisition}

Ten herbal medicines used in this experiment was purchased from HMAX (Jecheon, Korea), Kwangmyungdang Medicinal Herbs (Ulsan, Korea), and Omniherb (Yeongcheon, Korea) as shown in Additional file 1: Table S1. The origin of the materials was confirmed taxonomically by Prof. Je-Hyun Lee, College of Oriental Medicine, Dongguk University (Gyeongju, Korea) and Prof. Young-Bae Seo, College of Oriental Medicine, Daejeon University (Daejeon, Korea). A voucher specimen of each herbal medicine has been deposited at the K-herb Research Center, Korea Institute of Oriental Medicine (KIOM, Additional file 1: Table S1).

\section{Preparations of herbal extract}

Each dried sample was extracted three times with $70 \%$ ethanol by sonication for $60 \mathrm{~min}$ or $70 \%$ methanol by reflux for $90 \mathrm{~min}$. The extracted solution was filtered through filter paper (No. 2, $150 \mathrm{~mm} \varnothing$; Whatman, Maidstone, UK) under vacuum, evaporated at $40{ }^{\circ} \mathrm{C}$ using BÜCHI R-210 rotary evaporator (Flawil, Switzerland) under vacuum to dryness and then freeze-dried to give a powder using freezing dryer, PVTFD10RS (IlShinBioBase, Yangju, Korea). 
The amount and yield of extracted samples are summarized in Additional file 2: Table S2.

\section{Cell viability and kidney injury biomarker detect assays}

To evaluate the cell viability, HK-2 cells were seeded onto 96-well plates and then treated with cisplatin in serum-free media for $24 \mathrm{~h}$. The cell viabilities were determined using the Ez-cytox assay kit (DOGEN, Seoul, Korea). After removing the culture media, the cells were stained with a WST assay reagent for $1 \mathrm{~h}$ at $37{ }^{\circ} \mathrm{C}$ in a $5 \% \mathrm{CO}_{2}$ incubator. After seeding of $\mathrm{HK}-2$ cells into 6-well plates, the cell were treated with cisplatin, cisplatin + ten herbal medicines for $24 \mathrm{~h}$. Cell culture supernatants were applied into NGAL, KIM-1 pre-coated plates and according to the manufacturer's instructions (Cloud-Clone Corp, USA, cat. SEB388Hu, SEA785Hu, respectively). To determine whether low and high doses of cisplatin induce apoptosis or necrosis, cells treated with $400 \mu \mathrm{M}$ of cisplatin were assessed at 2, 4, and $6 \mathrm{~h}$, and cells treated with $10 \mu \mathrm{M}$ of cisplatin were assessed at 6,24 , and $48 \mathrm{~h}$. The absorbance was determined in lysates at $450 \mathrm{~nm}$ using an ELISA reader (VERSA Max; Molecular Devices, Sunnyvale, CA, USA).

\section{Release of lactate dehydrogenase and extracellular HMGB1 assay}

HK-2 cells were seeded in 96 well plate $\left(1 \times 10^{4}\right.$ cells/well $)$ overnight and treated with cisplatin, cisplatin + ten herbal medicines for $6 \mathrm{~h}$. LDH enzyme activity in culture medium was determined by the Cytoscan ${ }^{\mathrm{Tm}}$ LDH Cytotoxicity Assay Kit according to the manufacture instruction (G-Biosciences, USA, cat. 786-324). HMGB1 release was detected in the culture medium using a sandwich enzyme-linked immune sorbent assay (ELISA) according to the manufacturer's instructions, and the measurements were performed at $450 \mathrm{~nm}$ (Cloud-Clone Corp, USA, cat. SEA399Hu).

\section{ROS, JC-1 monomers detection, caspase activation and Annexin $\mathrm{V}$ binding PI staining}

HK-2 cells were seeded in 96 well plate $\left(1 \times 10^{4}\right.$ cells/well $)$ overnight and treated with cisplatin, cisplatin + Nelumbo nymphaea (NY), Paeonia suffruticosa (PS) for $30 \mathrm{~min}$. ROS production assays was stained by DCFDA cellular ROS detection assay kit according to the manufacture instruction (Abcam, Cambridge, USA, ab113851). The mitochondrial transmembrane potential was determined with JC-1 dye staining according to the manufacture protocol (Abcam, Cambridge, USA, ab113850). The fluorescence of the JC-1 monomer (green) was read in fluorescence plate reader with excitation/emission setting at 485/535 (Spectramax i3, Molecular Devices. Sunnyvale, USA). Activity of caspases were determined using a colorimetric caspase9, -3 assay kit (Abcam, Cambridge, USA, ab65608, ab39401, respectively). The assays were performed 60 piwell plates $\left(5 \times 10^{5}\right.$ cells/well $)$ by incubating cell lysis buffer. After lysis, we measured caspase assay kits according to the manufacture protocol. Apoptotic cell measures were conducted via Annexin V-FITC/PI staining. Adherent cells underwent the collection from centrifugation and then re-suspended in $500 \mu \mathrm{l} 1 \times$ binding buffer. The cells were stained with $5 \mu \mathrm{L}$ Annexin V-FITC and $5 \mu \mathrm{l}$ propidium iodide (PI) $(50 \mu \mathrm{g} / \mathrm{mL})$ and incubated at room temperature for $15 \mathrm{~min}$ in the dark. The cells were analyzed by a flow cytometry (Becton Dickinson FACS Vantage SE, Sanjose, USA).

\section{Experimental design}

The cells were divided to three group: control, cisplatininduced group and cisplatin + herbal medicine (dose at $100 \mu \mathrm{g} / \mathrm{mL}$ ). Herbal medicines were dissolved in distilled water (D.W.). Herbal medicines were stored at $-70{ }^{\circ} \mathrm{C}$ until used.

\section{In vivo study}

ICR mice (male, 7 weeks old) were purchased from Daehan Bio Link (ChungBuk, Korea) and acclimated for 1 week before the initiation of experiments. All animal procedures were approved by the Institutional Animal Care and Use Committee of the Korea Institute of Oriental Medicine (16-105). Mice were given an intraperitoneal injection (i.p.) of cisplatin $(20 \mathrm{mg} / \mathrm{kg})$ for 3 days. After NY, PS given an oral administration (300 $\mathrm{mg} / \mathrm{kg}$ ) for 3 days. Serum and urine were collected in stored at $-20^{\circ} \mathrm{C}$ before use.

\section{Statistical analysis}

All experimental results were calculated using $t$-test. All variables were analyzed using the GraphPad Prism 5.10 software (GraphPad Software Inc., San Diego, USA). Each experiment was performed at least three times. Statistical significance was indicated by ${ }^{*} p<0.05,{ }^{* * *} p<$ 0.01 and ${ }^{* * * *} p<0.001$.

\section{Result}

Cisplatin decreases cell viability and induces kidney injury biomarker in HK-2 cells

To assess the toxicity in HK-2 cells, MTT assay was conducted with cisplatin. Treatment with cisplatin for $24 \mathrm{~h}$ was decreased viability of HK-2 cells in dose-dependent manner (Fig. 1a). We found that significant decrease in cell viability at high dose and time-dependent manner (Fig. 1b). Because necrosis is characterized by an early disruption of the plasma membrane and cells passively release HMGB1 [12], a high dose of cisplatin $(400 \mu \mathrm{M})$ resulted in the time-dependent release of HMGB1 and the cellular necrosis indicator LDH in HK-2 cells (Fig. 1c and d). Next, we examined the effect of cisplatin on activity 

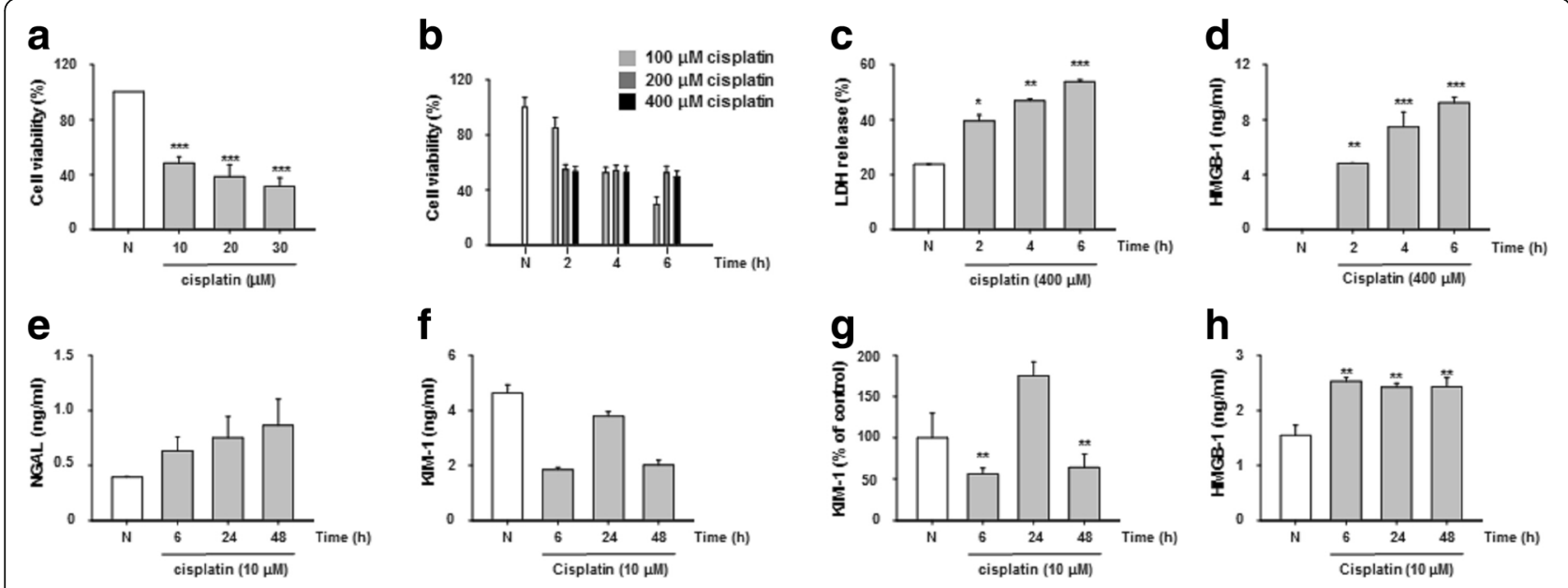

Fig. 1 Cisplatin was induced up to cell death and kidney injury biomarkers in HK2 cells. Cell viability of HK-2 cells was treated with cisplatin low dose-long time manner for $24 \mathrm{~h} \mathrm{(a)}$, and high dose-short time treatments for 2 to $6 \mathrm{~h}(\mathbf{b})$. Release of LDH (c) and HMGB1 (d) were treated with cisplatin $(400 \mu \mathrm{M})$ for 2 to $6 \mathrm{~h}$. Secretion levels of NGAL (e), KIM-1 (f, g) and HMGB1 (h) for 6 to 48 h. The statistical significance $\left({ }^{*} p<0.05\right.$, ${ }^{* *} p<0.01$ and $\left.{ }^{* * *} p<0.001\right)$ of the observed differences between cisplatin treated and control groups were tested by $t$-test

of the biomarkers: NGAL, KIM-1 and HMGB1, which are kidney injury molecules. The activity levels of NGAL and KIM-1 increased by $50 \%$ (Fig. 1e-g), which, compared to the control, increased the amount of HMGB1 in the culture media by $50 \%$ (Fig. 1h). NGAL, KIM-1 and HMGB1 concentrations can be increased by up to $50 \%$ during cisplatin treatment of HK-2 cells.

\section{Herbal medicines cell viability and their effects on NGAL and KIM-1 molecules}

Initially, we conducted herbal medicine toxicity assay in HK-2 cells that it provided the data on fixing the optimal dose as $100 \mu \mathrm{g} / \mathrm{mL}$ (Additional file 3: Figure S1). To determine whether herbal medicines protect against kidney injuries, we examined cell viability and biomarker expression after herbal medicine treatment in cells exposed to cisplatin. In previous studies, the reactive oxygen species (ROS) scavenger NAC was shown to protect against AKI [13]. An MTT assay was performed in HK-2 cells to investigate the effect of NAC under conditions of cisplatin treatment (Fig. 2a). Compared to the cell viability of cisplatin-treated cells (49\%), the cell viability (77\%) of cells pretreated with NAC was significantly increased. Additionally, the cell viability assay showed that 10 types of herbal medications protected against cell death (Fig. 2b). Furthermore, levels of the kidney injury biomarkers NGAL and KIM-1 were also markedly decreased from 20 to $50 \%$ in cells treated with the 10 types of herbal medicines (Fig. 2c and d).

HMGB1 was regulated by herbal medicine in high-dose cisplatin-treated HK-2 cells

During necrotic cell death, HMGB1 is released into the extracellular area and plays important roles as a damage- associated molecular pattern molecule in tubular epithelial cells [14]. Additionally, HMGB1 promotes kidney injury and reduces survival of tubular cells due to ischemia/reperfusion injury [15]. It is unclear whether herbal medicine can block the release of HMGB1 from the cell to the extracellular matrix; we observed that necrotic changes were inhibited by approximately $15 \%$ by LDH release (Fig. 3a), and HMGB1 (20 to 50\%) was decreased in herbal medicine-treated cells (Fig. 3b). These data indicate that herbal medicines, such as NY and PS, are potent effectors that protect against renal proximal tubular necrotic cell death.

Profiling of kidney injury biomarker changes that result in necrotic or apoptotic cell death

HMGB1 showed a 4-fold change (2 h), 6-fold change $(4 \mathrm{~h})$ and 7 -fold change $(6 \mathrm{~h})$ in cells treated with $400 \mu \mathrm{M}$ cisplatin and a 1.6-fold change $(6 \mathrm{~h}), 1.5$-fold change $(24 \mathrm{~h})$, and 1.5 -fold change $(48 \mathrm{~h})$ in cells treated with $10 \mu \mathrm{M}$ cisplatin. NGAL and KIM-1 showed around 1.0-fold change ( 2 to $6 \mathrm{~h}$ ) in cells treated with $400 \mu \mathrm{M}$ cisplatin. NGAL exhibited a 1.4-fold, a 1.7-fold and a 2.1 -fold change $(6,24$ and $48 \mathrm{~h}$, respectively) in cells treated with $10 \mu \mathrm{M}$ cisplatin. KIM-1 revealed around 1 -fold, a 1.7-fold and 1-fold change $(6,24$ and $48 \mathrm{~h}$, respectively) in cells treated with $10 \mu \mathrm{M}$ cisplatin. (Fig. 4). The data indicated that the expression levels of HMGB1, NGAL and KIM-1 notably varied with dose and time of exposure to cisplatin.

\section{Cisplatin-induced AKI was related to caspase activation in HK-2 cells death}

Cisplatin produces ROS which lead to activation of mitochondrial pathway of apoptosis [16]. We further 

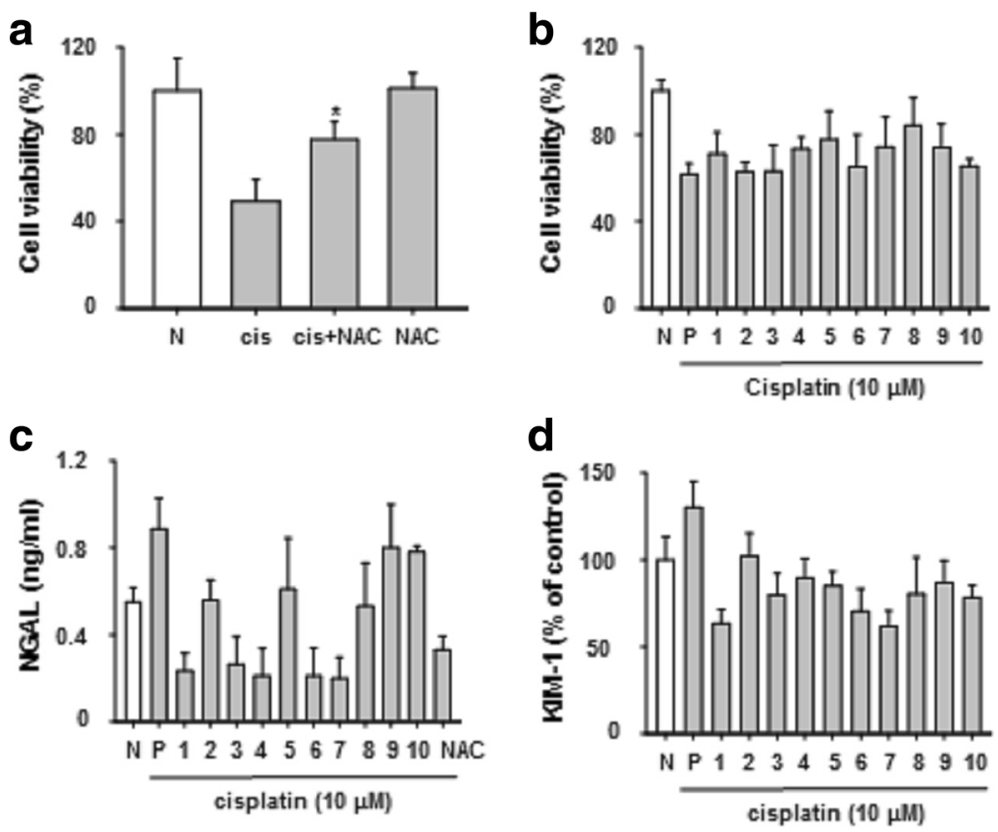

Fig. 2 Herbal medicines regulated NGAL and KIM-1 biomarkers. Pretreatment with NAC $10 \mathrm{mM}$ for $1 \mathrm{~h}$ and stimulated with cisplatin (10 $\mu$ M) for $24 \mathrm{~h}$ (a). Cytotoxicity was measured by MTT assay treatment with herbal medicine and cisplatin for $24 \mathrm{~h}$ (b). NGAL and KIM-1 were measured by ELISA (c and d). Lane 1:; Artemisia capillaris, Lane 2:; Houttuynia cordata, Lane 3:; Leonurus japonicas, Lane 4:; Nelumbo nymphaea, Lane 5:; Schisandra chinensis, Lane 6:; Akebia quinata, Lane 7:; Ligustrum japonicus, Lane 8:; Paeonia suffruticosa, Lane 9:; Phellodendron amurense, Lane 10:; Trichosanthes kirilowii. The statistical significance $\left({ }^{*} p<0.05\right)$ of the observed differences between cisplatin treated and cisplatin + NAC groups were statistically tested by $t$-test

studied that whether NY, PS inhibits production of ROS and apoptotic molecules. An ROS production and JC-1 green fluorescence were examined in HK-2 cells. NY, PS were decreased to ROS, JC-1 green fluorescence after cisplatin treatments (Fig. 5a and b). Next, further investigated the effect of NY, PS was induced by cisplatin-induced apoptosis, such as caspase-9, -3 activation. The level of caspase-9, -3 activation significantly decreased by NY, PS after cisplatin treatment (Fig. 5c and d). Apoptotic cell measures via Annexin V-FITC/PI staining were statistically different from $\mathrm{NY}$ and PS group (Fig. 5e).
Effects of NY, PS on kidney injury biomarkers, NGAL, KIM-1 in cisplatin-induced mice

To investigate whether NY, PS, protects kidney injuries, we examined in vivo study. Urinary, serum KIM-1 and NGAL levels a sensitive early time biomarkers cisplatin-induced AKI in mice $[17,18]$. Therefore we assessed in mice injected with cisplatin $(20 \mathrm{mg} / \mathrm{kg})$ for 3 days and after orally administration N. nymphaea, P. suffruticosa (300 $\mathrm{mg} / \mathrm{kg})$ for 3 days. Urinary and serum NGAL, KIM-1 levels were significantly decreased in cisplatin-induced AKI (Fig. 6a-d). These data implicated that NY, PS had effect on kidney injury biomarkers in cisplatin-induced AKI models.
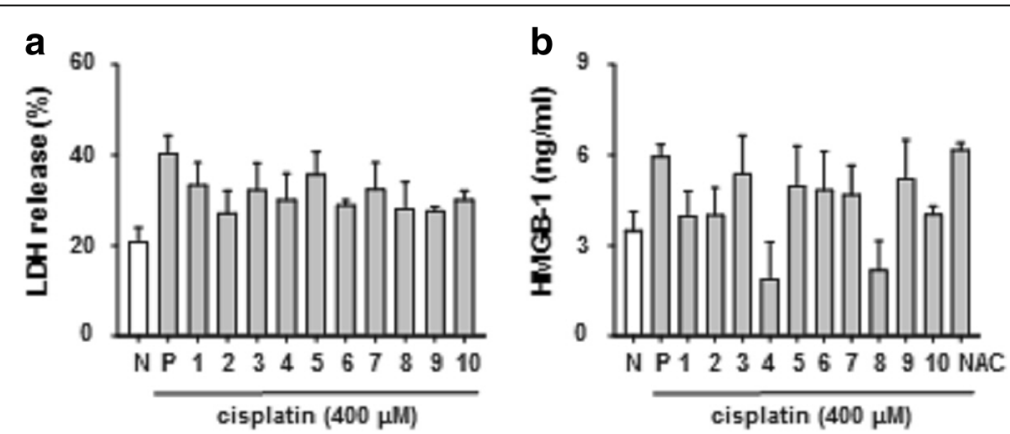

Fig. 3 HMGB1 was regulated by herbal medicines with high dose-treated cisplatin in HK-2 cells. HK-2 cells were treated with high - dose of cisplatin $(400 \mu \mathrm{M})$ for $6 \mathrm{~h}$. Herbal medicines decreased LDH (a), and HMGB1 (b). The levels of LDH, HMGB1 were measured by ELISA assay kits 

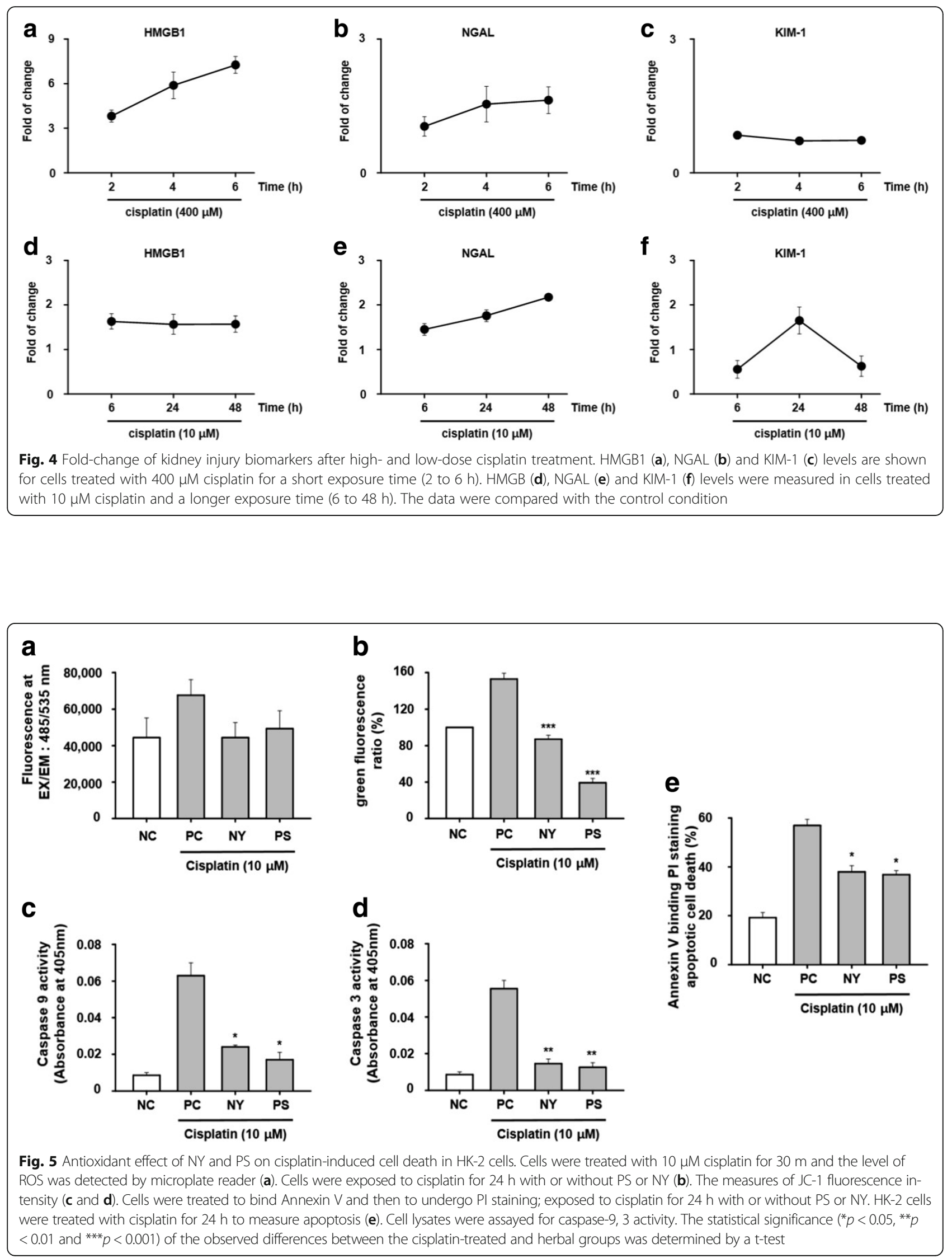

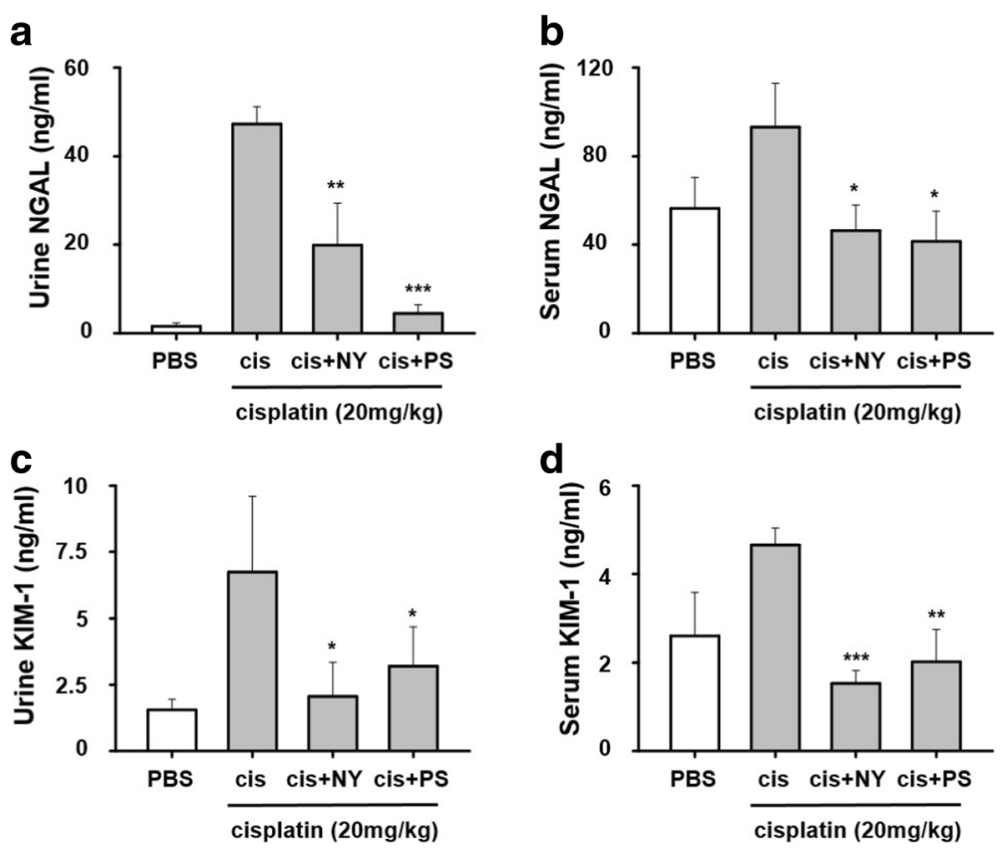

Fig. 6 Herbal medicines ameliorated cisplatin-induced kidney injury markers. Mice were given an intraperitoneal injection (i.p.) of cisplatin (20 mg/kg) for 3 days. After Nelumbo nymphaea (NY), Paeonia suffruticosa (PS) given an orally administration (300 mg/kg) for 3 days. Concentration of NGAL and KIM-1 were measured in urine and serum (a-d). All the values are expressed as mean \pm S.E.M., $n=3$ in each group. ${ }^{*}$, ** and *** statistically different from cisplatin at $p<0.05, p<0.01$ and $p<0.001$, respectively

\section{Discussion}

In this study, herbal medicines ameliorated organic and functional AKI in a dose- and time-dependent manner. NY and PS reduced the elevated levels of NGAL, KIM-1 and HMGB1 activities in ciaplatin-induced in vitro and in vivo settings. The NGAL levels are increased in urine after kidney injury due to the inhibition of kidney reabsorption in the renal tubule [19]. NGAL-induced apoptosis is caused by caspase activation and changes in mitochondrial membrane potential, which in turn increases intracellular iron accumulation [20,21]. HMGB1 is released by activated tubular cells and macrophages and is passively released by necrotic or damaged cells. Therefore, DAMPs may be secreted and expressed in the cytosol or nucleus and include heat-shock proteins, which cause tissue damage $[12,22]$. High-dose cisplatin-induced Poly (ADP-ribose) polymerase 1 activation contributes to necrosis in human, pig and mouse cells [7]. In this study, we observed biomarker modulation by herbal medicines within 6 and $24 \mathrm{~h}$ time frames after exposure to cisplatin concentrations of 400 and $10 \mu \mathrm{M}$, respectively.

Recently, herbal extracts have been shown to inhibit oxidative stress, inflammation and cisplatin-induced nephrotoxicity. PS can suppress nitric oxide and tumor necrosis factor- $\alpha$ (TNF- $\alpha$ ) and is related to the expression of the TLR4-NF-kB pathway in mice [23-25]. NY, Schisandra chinensis, and sappanone A are known to reduce cisplatin-induced kidney injury, asthma and chronic

Table 1 Comparative properties and known information on the studied herbal medicines regarding acute kidney injury

\begin{tabular}{|c|c|c|c|c|c|c|c|c|c|c|c|}
\hline & \multirow[b]{2}{*}{$\begin{array}{l}\text { Herbal } \\
\text { Medicine }\end{array}$} & \multicolumn{10}{|c|}{ The studied herbal medicines } \\
\hline & & $\begin{array}{l}\text { Artemisia } \\
\text { capillaris }\end{array}$ & $\begin{array}{l}\text { Houttuynia } \\
\text { cordata }\end{array}$ & $\begin{array}{l}\text { Leonurus } \\
\text { japonicus }\end{array}$ & $\begin{array}{l}\text { Nelumbo } \\
\text { nymphaea }\end{array}$ & $\begin{array}{l}\text { Schisandra } \\
\text { chinensis }\end{array}$ & $\begin{array}{l}\text { Akebia } \\
\text { quinata }\end{array}$ & $\begin{array}{l}\text { Ligustrum } \\
\text { lucidum }\end{array}$ & $\begin{array}{l}\text { Paeonia } \\
\text { suffruticosa }\end{array}$ & $\begin{array}{l}\text { Phellodendron } \\
\text { amurense }\end{array}$ & $\begin{array}{l}\text { Trichosanthes } \\
\text { kirilowii }\end{array}$ \\
\hline \multirow{3}{*}{$\begin{array}{l}\text { "Assay } \\
\text { results in } \\
\text { the study }\end{array}$} & NGAL & ++ & ++ & ++ & +++ & ++ & ++ & ++ & ++ & + & - \\
\hline & $\mathrm{KIM}-1$ & ++ & + & ++ & ++ & ++ & ++ & ++ & ++ & ++ & ++ \\
\hline & HMGB1 & ++ & ++ & - & +++ & + & + & + & +++ & + & + \\
\hline \multicolumn{2}{|c|}{ Information } & $\begin{array}{l}\text { Liver } \\
\text { function } \\
\text { recovery } \\
\text { activity }\end{array}$ & $\begin{array}{l}\text { Anti-fungal } \\
\text { activity and } \\
\text { used as a } \\
\text { hygiene } \\
\text { amenity }\end{array}$ & $\begin{array}{l}\text { Slight anti-uretic } \\
\text { activity and used } \\
\text { for postpartum } \\
\text { hemorrhage }\end{array}$ & $\begin{array}{l}\text { Used for } \\
\text { various } \\
\text { types of } \\
\text { hemorrhage }\end{array}$ & $\begin{array}{l}\text { Increasing } \\
\text { urinary } \\
\text { flow }\end{array}$ & $\begin{array}{l}\text { Maintains } \\
\text { urinary } \\
\text { bladder } \\
\text { flow }\end{array}$ & $\begin{array}{l}\text { Liver } \\
\text { function } \\
\text { recovery } \\
\text { and anti-uretic } \\
\text { effect }\end{array}$ & $\begin{array}{l}\text { Liver } \\
\text { function } \\
\text { recovery, } \\
\text { anti-uretic } \\
\text { effect and } \\
\text { increasing } \\
\text { WBCs }\end{array}$ & $\begin{array}{l}\text { Strong } \\
\text { anti-fungal } \\
\text { effect; efficacious } \\
\text { compound, } \\
\text { berberine } \\
\text { was developed. }\end{array}$ & $\begin{array}{l}\text { Anti-diabetes } \\
\text { and liver } \\
\text { dampness } \\
\text { effects }\end{array}$ \\
\hline
\end{tabular}


obstructive pulmonary disease [26-29]. However, few reports have examined the time- and concentrationdependent effects of NY and PS in cisplatin-induced kidney injuries (Table 1).

Induction of kidney injury biomarkers, such as NGAL and KIM-1, and HMGB1, exhibits different profiles during the course of chronological assessment. High-dose and short-term exposure to cisplatin can cause necrotic changes and HMGB1 release. These diagnostic biomarkers may reveal acute tubular necrosis [22]. However, a low dose and a long period after cisplatin treatment resulted in a lower quantity of HMGB1 release. Among the examined herbal medicines, NY and PS decreased HMGB1, NGAL and KIM-1 by $50 \%$ compared to the treatment-naïve group. Therefore, further experimental studies are warranted and clinically applicable.

In a previous study, paeonol was isolated from PS and investigated in a mouse model of lipopolysaccharide (LPS)-induced AKI. It also ameliorated serum creatinine and blood urea nitrogen (BUN) levels via modulation of serum inflammatory cytokines, such as TNF- $\alpha$, IL- $1 \beta$, and IL-6 [23]. Another of the isolated fractions, protocatechuic aldehyde, was reported to inhibit cisplatininduced decreases in renal function both in vitro and in vivo by attenuating oxidation and inflammation [30]. In future studies, we could examine the mechanisms by which NY and PS attenuate kidney injury in mice.

Collectively, as shown in Fig. 4 and Table 1, our study provides preliminary but promising evidence on biomarker activity profiles, which depends on the dose of (high or low) and exposure time (short or long) to cisplatin (HMGB1; 7-fold at $6 \mathrm{~h}$ with $400 \mu \mathrm{M}$; NGAL and KIM-1; 1.7 -fold at $24 \mathrm{~h}$ with $10 \mu \mathrm{M})$. Additionally, further studies should be conducted to prove translational application of herbal medicines for kidney injury patients with abnormal ischemia reperfusion injury conditions or sepsis.

\section{Conclusions}

The present study found that several herbal medicines have beneficial effects on AKI. Additionally, the use of different doses and the time profiles of cisplatin exposure differentially activated the selected kidney injury biomarkers, which increased necrosis and apoptosis in the renal tubular cell line and experimental animal. Ten herbal medicines, including PS and NY, exhibited potential against necrotic and apoptotic cisplatin-induced kidney injuries.

\section{Additional files}

Additional file 1: Table S1. List of herbal medicines. (DOCX $14 \mathrm{~kb}$ )

Additional file 2: Table S2. Sample information. (DOCX $12 \mathrm{~kb}$ )
Additional file 3: Figure S1. MTT assay was conducted with herbal medicines which dose range from 0.1 to $1 \mathrm{mg} / \mathrm{ml}$ was treated to herbal medicines for $24 \mathrm{~h}$. The $0.1 \mathrm{mg} / \mathrm{ml}$ concentration was chosen as the fixed dose. The cell viability of HK-2 cells treated with dose dependent herbal medicines. Lane 1: Artemisia capillaris, Lane 2: Houttuynia cordata, Lane 3: Leonurus japonicas, Lane 4: Nelumbo nymphaea, Lane 5: Schisandra chinensis, Lane 6: Akebia quinata, Lane 7: Ligustrum japonicus, Lane 8: Paeonia suffruticosa, Lane 9: Phellodendron amurense, Lane 10: Trichosanthes kirilowii. (JPEG 81 kb)

\section{Abbreviations}

AKl: Acute kidney injury; ATCC: American Type Culture Collection; BUN: Blood urea nitrogen; HMGB1: High mobility group box protein 1; IL-18: Interleukin18; KIM-1: Kidney injury molecule-1; NAC: N-acetylcysteine; NGAL: Neutrophil gelatinase-associated lipocalin; NY: Nelumbo nymphaea; PS: Paeonia suffruticosa; ROS: Reactive oxygen species; SCr: Serum creatinine

\section{Acknowledgements}

Thanks Miss Chae-Rim Lee for assisting the experiments by Ministry of Health \& Welfare through the Korea Health Industry Development Institute.

\section{Funding}

This study was supported by the Traditional Korean Medicine R\&D program funded by the Ministry of Health \& Welfare through the Korea Health Industry Development Institute (KHIDI, Grant \# HI16C0948).

Availability of data and materials

All the data are contained and descripted within the manuscript. The corresponding author will provide if requested.

\section{Authors' contributions}

SM Oh wrote the first draft of the manuscript. DS Oh designed the study, analyzed the data, and drafted the manuscript. DS Oh and SM Oh made substantial contributions to study conception and design, as well as analysis and interpretation of data, and drafting the manuscript. SM Oh, G Park and $\mathrm{SH}$ Lee performed the experiments. CS Seo and HK Shin analyzed the Quality controls. All authors read and approved the final manuscript.

Ethics approval and consent to participate

Not applicable.

\section{Consent for publication}

Not applicable.

\section{Competing interests}

The authors declare that they have no competing interests.

\section{Publisher's Note}

Springer Nature remains neutral with regard to jurisdictional claims in published maps and institutional affiliations.

Received: 14 August 2017 Accepted: 7 December 2017

Published online: 19 December 2017

References

1. Rewa O, Bagshaw SM. Acute kidney injury-epidemiology, outcomes and economics. Nat Rev Nephrol. 2014;10(4):193-207.

2. Levey AS, Becker C, Inker LA. Glomerular filtration rate and albuminuria for detection and staging of acute and chronic kidney disease in adults: a systematic review. JAMA. 2015;313(8):837-46.

3. Doi K, Katagiri D, Negishi K, Hasegawa S, Hamasaki Y, Fujita T, et al. Mild elevation of urinary biomarkers in prerenal acute kidney injury. Kidney Int. 2012:82(10):1114-20.

4. Nortier JL, Vanherweghem JL. Renal interstitial fibrosis and urothelial carcinoma associated with the use of a Chinese herb (Aristolochia fangchi). Toxicology. 2002;181:577-80. https://doi.org/10.1016/S0300-483x(02)00486-9. PubMed PMID: WOS:000180646400094

5. Ozkok A, Edelstein CL. Pathophysiology of cisplatin-induced acute kidney injury. Biomed Res Int. 2014;2014:967826.

6. Yao X, Panichpisal K, Kurtzman N, Nugent K. Cisplatin nephrotoxicity: a review. Am J Med Sci. 2007;334(2):115-24. 
7. Park S, Yoon SP, Kim J. Cisplatin induces primary necrosis through poly(ADP-ribose) polymerase 1 activation in kidney proximal tubular cells. Anat Cell Biol. 2015;48(1):66-74.

8. Lieberthal W, Triaca V, Levine J. Mechanisms of death induced by cisplatin in proximal tubular epithelial cells: apoptosis vs. necrosis. Am J Phys. 1996; 270(4 Pt 2):F700-8.

9. Shlipak MG, Day EC. Biomarkers for incident CKD: a new framework for interpreting the literature. Nat Rev Nephrol. 2013;9(8):478-83.

10. Lotze MT, Tracey KJ. High-mobility group box 1 protein (HMGB1): nuclear weapon in the immune arsenal. Nat Rev Immunol. 2005;5(4):331-42.

11. Sohn SJ, Kim SY, Kim HS, Chun YJ, Han SY, Kim SH, et al. In vitro evaluation of biomarkers for cisplatin-induced nephrotoxicity using HK-2 human kidney epithelial cells. Toxicol Lett. 2013;217(3):235-42.

12. Rovere-Querini P, Capobianco A, Scaffidi P, Valentinis B, Catalanotti F, Giazzon $\mathrm{M}$, et al. HMGB1 is an endogenous immune adjuvant released by necrotic cells. EMBO Rep. 2004;5(8):825-30.

13. Lee JH, Jo YH, Kim K, Lee JH, Rim KP, Kwon WY, et al. Effect of Nacetylcysteine (NAC) on acute lung injury and acute kidney injury in hemorrhagic shock. Resuscitation. 2013;84(1):121-7.

14. Zheng SX, Pan YB, Wang CR, Liu YP, Shi M, Ding GH. HMGB1 turns renal tubular epithelial cells into inflammatory promoters by interacting with TLR4 during sepsis. J Interf Cytok Res. 2016;36(1):9-19.

15. Chen Q, Guan X, Zuo X, Wang J, Yin W. The role of high mobility group box 1 (HMGB1) in the pathogenesis of kidney diseases. Acta Pharm Sin B. 2016;6(3): 183-8.

16. Miller RP, Tadagavadi RK, Ramesh G, Reeves WB. Mechanisms of Cisplatin nephrotoxicity. Toxins (Basel). 2010;2(11):2490-518.

17. Vaidya VS, Ramirez V, Ichimura T, Bobadilla NA, Bonventre JV. Urinary kidney injury molecule-1: a sensitive quantitative biomarker for early detection of kidney tubular injury. Am J Physiol Renal Physiol. 2006;290(2):F517-29.

18. Ozkok A, Ravichandran K, Wang Q, Ljubanovic D, Edelstein CL. NF-kappa B transcriptional inhibition ameliorates cisplatin-induced acute kidney injury (AKI). Toxicol Lett. 2016;240(1):105-13.

19. Wang YH, Liu YH, He GR, Lv Y, Du GH. Esculin improves dyslipidemia, inflammation and renal damage in streptozotocin-induced diabetic rats. BMC Complement Altern Med. 2015;15:402.

20. Chien MH, Ying TH, Yang SF, Yu JK, Hsu CW, Hsieh SC, et al. Lipocalin-2 induces apoptosis in human hepatocellular carcinoma cells through activation of mitochondria pathways. Cell Biochem Biophys. 2012;64(3):177-86.

21. Xu G, Ahn J, Chang S, Eguchi M, Ogier A, Han S, et al. Lipocalin-2 induces cardiomyocyte apoptosis by increasing intracellular iron accumulation. J Biol Chem. 2012;287(7):4808-17.

22. Scaffidi P, Misteli T, Bianchi ME. Release of chromatin protein HMGB1 by necrotic cells triggers inflammation. Nature. 2002;418(6894):191-5.

23. Fan HY, Qi D, Yu C, Zhao F, Liu T, Zhang ZK, et al. Paeonol protects endotoxin-induced acute kidney injury: potential mechanism of inhibiting TLR4-NF-kappaB signal pathway. Oncotarget. 2016;7(26):39497-510.

24. Lee H, Lee G, Kim H, Bae H. Paeonol, a major compound of moutan cortex, attenuates Cisplatin-induced nephrotoxicity in mice. Evid Based Complement Alternat Med. 2013;2013:310989.

25. Lin YR, Wu MY, Chiang JH, Yen HR, Yang ST. The utilization of traditional Chinese medicine in patients with dysfunctional uterine bleeding in Taiwan: a nationwide population-based study. BMC Complement Altern Med. 2017;17(1):427.

26. Jin J, Li M, Zhao Z, Sun X, Li J, Wang W, et al. Protective effect of Wuzhi tablet (Schisandra sphenanthera extract) against cisplatin-induced nephrotoxicity via Nrf2-mediated defense response. Phytomedicine. 2015; 22(5):528-35.

27. Paudel KR, Panth N. Phytochemical profile and biological activity of Nelumbo Nucifera. Evid Based Complement Alternat Med. 2015;2015:789124.

28. Kang L, Zhao H, Chen C, Zhang X, Xu M, Duan H, Sappanone A. Protects mice against cisplatin-induced kidney injury. Int Immunopharmacol. 2016; 38:246-51.

29. Yang X, Xue L, Zhao QY, Cai CL, Liu QH, Shen JH. Nelumbo nucifera leaves extracts inhibit mouse airway smooth muscle contraction. BMC Complem Altern M. 2017:17(1):159.

30. Gao L, Wu WF, Dong L, Ren GL, Li HD, Yang Q, et al. Protocatechuic aldehyde attenuates cisplatin-induced acute kidney injury by suppressing nox-mediated oxidative stress and renal inflammation. Front Pharmacol. 2016;7:479.

\section{Submit your next manuscript to BioMed Central and we will help you at every step:}

- We accept pre-submission inquiries

- Our selector tool helps you to find the most relevant journal

- We provide round the clock customer support

- Convenient online submission

- Thorough peer review

- Inclusion in PubMed and all major indexing services

- Maximum visibility for your research

Submit your manuscript at www.biomedcentral.com/submit

) Biomed Central 